\title{
"Flowers of the Dawn": Mediator and Facilitators of Social Justice for Transnational Laborers in the Thai-Burmese Borderland of Mae Sot District, Tak Province, Thailand
}

\author{
Kettawa Boonprakarn ${ }^{1}$, Jedsarid Sangkaphan ${ }^{2}$, Benjaporn Deekhuntod ${ }^{3} \&$ Nuntharat Suriyo $^{3}$ \\ ${ }^{1}$ Faculty of Liberal Arts, Prince of Songkla University, Hat Yai District, Songkhla Province, Thailand \\ ${ }^{2}$ Graduate School, Hatyai University, Hat Yai District, Songkhla Province, Thailand \\ ${ }^{3}$ Freelance Researcher, Thailand \\ Correspondence: Kettawa Boonprakarn, Faculty of Liberal Arts, Prince of Songkla University, Hat Yai District, \\ Songkhla Province 90110, Thailand. E-mail: kettawa@hotmail.com
}

Received: September 2, 2013 Accepted: January 17, 2014 Online Published: February 26, 2014

doi:10.5539/ass.v10n6p7 URL: http://dx.doi.org/10.5539/ass.v10n6p7

\begin{abstract}
"Flowers of the Dawn" is a group of transnational laborers who are successful in helping their fellow laborers in a wide range of problems. The group understands problems better, is more trustworthy, and more able to solve problems than other groups that also help laborers. The influx of "cheap labor" and "illegal laborers" has caused chronic problems for Thai society and the laborers themselves at the individual, local and national levels. The problems have not been seriously addressed and the laborers themselves have become "the problems" that cause many difficulties in racial bias which in turn leads to inappropriate solutions to the problems and hence the real causes of the problems have not been overlooked. "Flowers of the Dawn" is a group of mediators and facilitators of social justice that targets transnational laborers fleeing from Myanmar and those who have been in Mae Sot and nearby areas. Assistance provided by the group has helped mitigate the problems resulting from government officials' negligence or by operators' exploitation of laborers. Even though not all the problems can be solved successfully, at least such assistance can make business operators and government officials see the importance of the problems of human rights and address them accordingly.
\end{abstract}

Keywords: mediators and facilitators of social justice, transnational laborer, human rights, illegal laborer, flowers of the dawn, YCOWA, Thai-Burmese borderland, Mae Sot

\section{Introduction}

The strategic location of Mae Sot on the East-West corridor, which runs from Vietnam and Laos, through Thailand and on to Myanmar has prompted the Thai government to make Mae Sot a special economic zone. This was followed by the construction of a four-lane highway to link Muang Tak District and Mae Sot District, and the construction of the second Thai-Myanmar Friendship Bridge in 2008 with the reason that it can be developed into an International Bridge that not only links Mae Sot in Thailand and Myowaddy in Myanmar, the two trading towns but also strengthens Mae Sot's being a base for textile production, wood processing, furniture, jewelry, and livestock of the frontier for Thailand and the world. As a result, investors from both national and international have chosen to establish many businesses and industrial facilities (Sorat, 2009). Simultaneously, demand for cheap labor from the neighboring Myanmar to reduce production cost increases. The latest data obtained show that the number of transnational laborers is 70 percent higher than local laborers (Myanmar firms initially established themselves Thailand in 2009). It is remarkable that these laborers are not only fleeing unrest, but also seeking higher income and better life. (Zaw, interviewed on January 11, 2012).

Nevertheless, it is undeniable that various incidents and problems have resulted from the influx of "cheap labor" and "illegal labor" and has affected Thai society and transnational laborers themselves at the individual, social and national levels for some time. There is often news about violence among transnational laborers, illegal migration, drug trafficking or news about some government organizations that have to allocate resources budget for medical care for unregistered workers as well as news about unfair treatment by employers It is surprising that no solution to these problems has ever been found. 
On the contrary, there is a view that these transnational laborers themselves are "the problems". This in turn causes other complications that are considered issues directly related to ethnic bias that leads to problem-solving that does not correspond with the causes (Kosaiyakanon, 2004).

In the above phenomena, the transnational workers themselves could not sue the other parties for compensation because they do not know the Thai language or Thai laws, they have no lawyer, and more importantly, they have no money to process the case. Consequently, the transnational workers usually think that they cannot sue anyone and they cannot win any cases in the foreign country. Such phenomena increase difficulties and hardships for the transnational workers. Therefore, help offered to them by the Flowers of the Dawn is help for fellow human beings. The Flowers of the Dawn is a group formed by transnational laborers themselves to help those who are exploited by employers. The group and the workers are from the same country and speak the same language so they understand each other well. The group helps in providing shelter when transnational workers first arrive Thailand and are not yet to find a job. They also help workers whose cases are in court by finding lawyers for them, provides knowledge of labor rights and human rights. Additionally, the group is also a social network that links with local government agencies, local NGOs, and sources of funding from outside the country to support the continued work of the group. The Flowers of the Dawn helps transnational workers to survive amidst hardships and this makes the small workers feel as if they have new lives. The Flowers of the Dawn is, therefore, seen as the mediators and facilitators of social justice.

The above phenomena with the helping process for transnational laborers by the group "Flowers of the Dawn" show us; the research team that the group is the key to explanation of the group's being mediators and facilitators of social justice. It is expected that the "Flowers of the Dawn" will be able to negotiate with power groups, namely groups of factory operators and groups of government officials that are groups with influence and authority in the area. This will lead to the concepts and practice in being mediators and facilitators of social justice in the Thailand-Myanmar border area.

\section{Objective}

To investigate the concepts and practice of the group "Flowers of the Dawn" as mediators and facilitators of social justice that provides help for transnational laborers.

\section{Important Concepts in the Study and Literature Review}

The researchers selected the following concepts as the main instruments in explaining the social network phenomenon between the "Flowers of the Dawn" as being mediators and facilitators of social justice for transnational laborers in the area where they cross the border in Mae Sot. They are: 1) Wilson and Donnan (1998)'s concept of borderlands, 2) Boissevain (1974)'s concept of social networks, and 3) de Certeau (1984)'s concept of everyday life practice as follows.

\subsection{Concept of Borderlands}

Wilson and Donnan (1998) presented borderlands in an anthology entitled Border Identities: Nation and State at International Frontiers and explained that borderlands are areas reflecting identities of diverse peoples that are not found in other places of the state, and different views of a geographical state can contribute to different looks and characteristics of each borderland. Walker (1997) presented people who are traders that negotiate trading with national states through mechanisms, agreements, rules and regulations. This mean that not only nation states have power in designation of rules along the borders, but also people living in the borderlands can create and negotiate meanings related to borderlands through trading networks. This corresponds with a study by Boonprakarn (2010) who sees that Muslim traders negotiate not only with rules and regulations of cross-border trading, but also Islamic principles on the Thailand-Malaysia border. In addition, Gupta and Ferguson (2001, pp. 40-41) view the fact that many different people physically travel across borders including traders, cross-border businessmen, tourists, and migrants in the third world countries who subsequently migrate to first world countries is a phenomenon that challenges the power of the state.

Leach (1960) in his article on The Frontiers of Myanmar notes that in the classification of people from the geographical regions of Myanmar, different geo-ecological regions that are hills and valleys are used as important natural fortifications that require understanding in that they are borders for different groups of people in the nation state. The geo-ecological differences affect people's worldviews and social practice in many ways that bring about divisions in political, economic, and cultural systems between people living on the hills and those in the valleys. Tsing (1960), and Lavie and Swedenburg (1996) give importance to analysis of different power groups around the borderline; however, these studies regard the borderland as a political issue of people with power not people who drive the economics of the nation state. Tsing (2000) sees globalization as creating 
borderlines between classes of people that obstruct people with low income to access communication technology that links data and information across the border while facilitating other groups of people with cross-border communication that cuts through limitations of national states. Horstmann (2002) views that borders have leakages, and people at the borders adapt themselves, especially many stateless, displaced, cross-border people with different cultures, and they migrate across the borders. Solomon (1970)'s study on Boundary Concepts and Practices in Southeast Asia describes interestingly the differences between the East and the West's worldviews and understanding of the border that in the East, having the borderlines means keeping security of the borderlines attaching importance to prohibition of invasion of political power between countries at the national level. Nevertheless, the migration of people, and the movement of resources at a lower level are difficult to control, as can be seen in people routinely migrating across borders and becoming transnational laborers.

The Mae Sot border has become an area where the impact of people of various ethnic and cultural groups has developed this region to be trading area overtime. As a result, many academics are interested in conducting studies about various aspects of the Mae Sot area. Nevertheless, the problem of oppressed workers exploited by employers and hardship of factory work remains. Thus, a group such as the Flower of the Dawn that supports transnational workers in the area, especially in the problems faced by these workers so that they can survive, is one answer. The group, the Flowers of the Dawn, which has become mediators and facilitators of social justice since 1989 in the Mae Sot borderlands, has been connected with other social networks and other organizations to help transnational workers in terms of labor rights and human rights.

\subsection{Concepts of Social Networks}

Boissevain (1974) states that a social network must be originated from a person who is the center before the scope of the network is expanded. Lin (1982; cited in Suwanatchariya, 2006, p. 111) describes the types of social networks and economic behavior created by strong relationships that are similar to those found in family organizations in relation to survival and job seeking. Survival requires the facilitation of many channels including those activated by state officials, neighbors, or people they meet by chance. These are ways that dictate individuals' economic routes. Chantarawongkitti and Boonprakarn (2013) found that the hope of laborers stems from creating economic networks through animal lottery in which they play in groups in hope that it is another way of getting some money to support their families. Likewise, Samosorn and Boonprakarn (2011) found that in the selling and buying of animal lottery tickets, there are networks of sellers, buyers, and investors who are interdependent and help each other. The reason why the underground lottery network has remained so long in Thailand that it gives the middle class hope for monetary reward from winning the lottery and this is deemed another way of building complex economic networks. Thongsakul and Boonprakarn (2012) created a social network through the mechanism of defining the tea space in Khu Tao Community. It is an area for social practice of the community, talking over a cup of tea through the space of the Masjid, village headman's home, and the meeting hall in order to solve problems of drugs, teenagers, and living condition of people in the community.

The case of the "Flowers of the Dawn" is similar as it has become mediators and facilitators of social justice and created a social network of transnational workers which has never ignored negative situations transnational workers who cannot find themselves in. Additionally, "the Flowers of the Dawn" has been successful in being mediators and facilitators of social justice by beginning its work process through cooperation among members and concerned parties. From one a factory and from small issues, it has gradually expanded to cover more areas and more extensive issues at the same time as seeking new knowledge and methods that are better suited to its work. New communication system and innovations are used as tools to create good and meaningful relationships among members. Moreover, the researchers found that transnational workers also use social networks as important mechanisms in traveling from their motherland to the Mae Sot borderlands to seek for better conditions.

\subsection{Concepts of the Practice of Everyday Life}

A study by de Certeau (1984) found that activities involved in the practice of everyday life have a work process of "tactics" hidden in them such as in a conversation, reading, traveling, shopping and others. The reasons are to win, negotiate, and impose authoritative relationships. The work of "tactics" tells us about insinuating in the power space, to survive (make do/get by) or poaching. These things happen in a forced situation. The practice of everyday life is a "tactic" of a battle without certain strategies but depends on the situation, and whenever there is an opportunity, they take it. The important point of the practice of everyday life is paying close attention to the "action" and "method" of negotiation and authoritative relationship that is non-oppositional binary but a cycle of authoritative relationship that defines meaning for them. However, the most important of all is to provide being the otherness with recognition and a voice to propose a way or a channel where everyday life can show its 
potential in making change for itself (Khunphon, 2007; citing Highmore, 2002). Tangseefa (2004)'s study challenges the important concept of Appadurai (2000) and questions who the moving people are and it is certain that these moving people are different from other people in general who are protected by law as people who are displaced have no law to protect them enough to cope with the cross national public sphere. What is more interesting is the use of ordinary life along with imperceptible naked life by giving importance to people being forced to be displaced persons. In their practice of everyday life, "Karen" has different ways of existence from refugees or displaced people because the situation they have to face is the change of being forced displaced people to being refugees, in the Thai state, who flee from a battle. Thus, this study opens a space for the forced displaced Karen to confirm their identity and to have a voice that is never recognized or heard so that the world recognizes and hears them.

According to a study by Sretthachua (2009), the tactics of the practice of everyday life is incorporated with the concept of the transnational minorities in describing life of cross border people who are illegal transnational laborers. After the area of Myanmar has been developed into part of the Greater Mekong Sub-region (GMS), that is a regional border crossing, it is found that crossing the border to work depends on the labor trafficking with Laotian brokers. Laborers have to pay four to five thousand baht each time, and these laborers are sent to do hard physical work or they are "sold per head" between traffickers while sending money back home costs them to pay through the unofficial "Border Bank" where their money is deducted for expenses. They believe that a good border bank must be honest. This indicates that the subjects of the research use the identity of being Laotian and the reason of morality in their cross border operations. For people who have no money, they fall victims to the cross border labor trafficking while transferring money over the border imitates a commercial bank transaction but with the use of morality based on the old economic system for negotiation.

Boonprakarn (2008) studied the level of the practice of everyday life of people who wear cross border clothing without being managed by materialism at all but rather negotiate by wearing the clothing and make use of such clothing in various ways, for example, the occasion, and the place they are in or the place where they identify themselves. Moreover, it was found that taking goods across the border from Thailand is with a risk, and therefore, people who transport goods must negotiate with the rules and regulations of the nation state where they have to face uncertainty. This is a movement from one set of authoritative relationship to another that is different. This is in accordance with Doorairajo (2002)'s account of Nayu, a young boy who went out from his home in Pattani when there was scarcity of fishery resources to work in a Tom Yam Kung restaurant in Malaysia where he had to negotiate with the rules for border crossing so that he could survive.

Similarly, even though the phenomenon of transnational laborers in Mae Sot and its suburb may be at a local level, state or national, or world, transnational laborers are found to be oppressed by different authoritative groups from entrepreneurs, state officials, or their fellow transnational laborers. Therefore, the researchers are interested in using de Certeau's concept of the practice of everyday life in describing the phenomenon of the interaction between transnational laborers and various authoritative groups through the group "Flowers of the Dawn" that has become mediators and facilitators of social justice.

\subsection{The Concepts Used in the Study}

The researchers employ Wilson and Donnan's (1998) concept in analyzing the identity of the complex borderland with diversity. The Mae Sot borderland is can be considered geographically and politically. Within the area the border follows the course of the Mei River, while the transnational workers make use of the cover provided by the forests and mountains to flee from the situation in Myanmar and cross into Thailand. The Thai government's policy of turning Mae Sot into a special economic zone has encouraged businesses to establish factories in the area because they can benefit from hiring legal transnational workers on low wages. These illegal workers prefer to work in Mae Sot even though they can earn more working in interior provinces and Bangkok because they do not face the difficulties encountered when traveling through Thai government checkpoints. Therefore, traveling through natural checkpoints that are the mountainous area of Tak Province is better for them. As a result, there are a large number of transnational workers living and working in the Mae Sot borderland. In analyzing the workers' crossing the border and traveling to Mae Sot, Boissevain (1974)'s concept, and de Certeau (1984)'s concept on the practice of everyday life are used. These concepts were also used to analyze the networking by the "Flowers of the Dawn" with NGOs and CBOs. The aims of the network were to identify lawyers, proceed with legal actions, find interpreters and sources of funding. During the process of helping workers when they first arrived in the Mae Sot borderlands and had no place to stay, a safe house was provided for them. In the safe house, they are trained to use sewing machines and how to sew before being taken to an factory whose owner knows staff members of the network. In addition, these workers are helped by networks of transnational workers and when injustice is encountered, the network calls the "Flowers of the Dawn" for further 
help and support. The "Flowers of the Dawn" has good relations with Thai government officials and often participates in activities on important days to tighten their relationship and for Thai officials to get to understand transnational workers from Burma better.

\section{Research Methodology}

\subsection{Research Area}

The research team selected the area of Mae Sot District, Tak Province as the main area while other areas related to transnational laborers were not excluded such as areas related to Yaung Chi Oo group and the areas nearby where the research team went to collect data. However, the research team was especially interested in Mae Sot itself because it is the primary "starting area" for transnational laborers in Thailand. The geographical characteristics of this area make it convenient for people to cross the border back and forth. There are many factories and small businesses operating industrial facilities scattered all over the area. Many important groups of ethnic laborers live in this area where several support organizations that provide help for transnational laborers are also located. They are groups of NGOs and CBOs that deal with laws about human rights as well as those designed to protect women and children, and healthcare.

\subsection{Key Informants}

A total of 23 key informants were recruited for this study consisting of 6 staff members of the "Flowers of the Dawn", 7 transnational laborers of various ethnic groups who came for employment in Mae Sot, namely Tai, Karen, Mon, Pa-long, Pa-o, Tawai and Burmese, 2 business owners, 2 government officials, 2 MAP-Foundation staff members, 2 LLC staff members, 1 HRDF staff member and 1 MTC staff member.

\subsection{Data Collection}

Data were collected from documents and research related to the history of transnational laborers in Mae Sot and from documents about the work and activities done by the Flowers of the Dawn and other associated groups.

\subsubsection{Field Data Were Collected as Follows}

1) Observing how staff members of the "Flowers of the Dawn" work; how they help workers, how they deliver training on the use of sewing machines, how they do activities with officials from the MAP-Foundation coordinate to assist workers with legal matters; the living conditions and way of life of transnational workers, the geo-ecological conditions of Mae Sot District, and individuals in the industrial facilities.

2) Conducting in-depth interviews with key informants to obtain data about the concept of the establishment of the "Flowers of the Dawn" and its practice in being the mediators and facilitators of social justice, as well as its social networking in cooperation with government officials, lawyers, attorneys in facilitating the helping process, and mitigation of problems between transnational workers and employers.

\subsection{Data Analysis and Data Testing}

In testing the data, the researchers used triangulation methods while collecting data in the field by testing with the sources, people, places, and time. In data analysis, the data gathered from related documents, observations and interviews were categorized according to the study issues, for example, the concepts behind the establishment of the "Flowers of the Dawn", its operations in helping workers and social networking by connecting with NGOs and INGOs to request help related to sources of funding, legal issues, interpreters, and lawyers. Consequently, each issue was decoded and interpreted to identify characteristics of the phenomenon, and then they were inductively concluded, and finally presented through the descriptive method.

\section{Result and Discussion}

\subsection{The Establishment Concept of the Flowers of the Dawn}

There had been chaotic political situations in Myanmar which eventually reached its peak when the " 8888 uprising" took place in the 8th day of the 8th month in the year 1988 and General Sein Lwin became president of the country (July 27, 1988-August 12, 1988). He ordered soldiers to shoot students and other people who protested against dictatorship; as a result, about 3,000 were killed. He had to step down. Soldiers who shot students were made to believe that students were "communist rebels" (8888 Uprising in Myanmar, 2012)

The coup d' etat in 1988 destroyed the formation of democracy, the federal system, and the freedom of the media (Kasetsiri, 2011, pp. 86-87). After that political leaders and activists had to flee and set up home in the forested area controlled by minority groups, especially in the area of the Karen National Union (KNU) under General Saw Bo Mya. The KNU is a troop of Karen ethnic minorities that has been fighting against the Burmese government for over 60 years from its base near the border opposite Phop Phra District and Mae Sot District of 
Tak Province of Thailand (Kasetsiri, 2011, pp. 86-87).

In Thailand during the period 1988-1991, General Chatchai Choonhavan, the Prime minister of Thailand at that time, announced the introduction of the policy of "Changing the battlefield to the market place". This was a turning point in Thailand's foreign policy with its neighbors because the focus was on economic relations with neighboring countries rather than the country's security. During that time, Burmese soldiers continually attacked troops from the ethnic minorities along the Thailand-Myanmar border. The ethnic minorities whose troops were affected were the Mon, Karen, Kaya, and Tai Yai resulting in many people fleeing over the border to Thailand. From 1990, migration to Thailand was different from the beginning (1962-1988) because the people were fleeing in much larger groups of 100 people or more. Sometimes the population of an entire village totaling 2,000-3,000 moved into Thailand. They migrate to live in agricultural, industrial and business areas. There are more people moving in to live permanently than before (Trichot, 2005). This is corresponds with a study by Horstmann (2002) who states that the border porous and a large number of people cross the border to Thailand because of Myanmar's politics. People moving across the border use social networks (Line, 1982; cited in Suwanatchariya, 2006 , p. 111) that were built based on strong inter-family relationships. In the family organization, there are relationships assist with settling and finding jobs. Settlement can be assisted in many ways such as through government officials, neighbors, or people we meet by chance. Because transnational workers migrate to escape from political problems and persecution, they migrate in large groups including people of entire villages, Thai government officials have to allow them to live temporarily.

It was the same for Moe Sway in 1988, he and his fellow students and Burmese people protested against the Myanmar's military regime. After the suppression by the military regime, he escaped and joined KNU (Karen National Union) to fight against the Myanmar military government. In 1997 he worked with ABSDF (All Myanmar Students Democratic Front) trying to help laborers. The main ideology of the group was to change the Burmese government because the change would lead to ability to help a million laborers along the border. He came to Mae Sot to join Labor Day activities where leaders in the meeting talked about the future of laborers, but not their poor living conditions, unfair wages and injustice. Therefore, he asked ABSDF to provide help for laborers but ABSDF did not agree, and consequently, he left the group to live in Mae Sot because his ideology and the group's were different. Moe Sway together with an American friend interviewed transnational laborers working on farms and in factories in order to learn about the problems faced by workers. He learned that the transnational laborers were paid a fraction of the minimum wage and were living in terrible conditions. When factories were closed down and laborers were laid off without pay and compensation, the laborers did not dare sue the factory owners because they are illegal transnational laborers, they are not educated and they do not know the Thai language. Thai Labor Department Offices do not have interpreters to help transnational laborers, so they have put up with the situation (Sway, Interviewed on 11 January 2012).

Moe Sway and some fellow Burmese who shared the same ideology formed themselves into a group in July 1999 called Yaung Chi Oo Worker's Association (YCOWA) meaning "Flowers of the Dawn" in order to understand the problems and provide effective help to address the problems faced by the workers. The group aims to improve working and living conditions for Burmese transnational laborers in the Mae Sot District of Thailand. The organization focuses on protecting the rights of the workers and providing knowledge about their rights, supporting their healthcare, and facilitating their social activities. Additionally, YCOWA also provides help for various Burmese labor networks in Mae Sot, Bangkok and other provinces in the southern part of Thailand in relation to labor laws and their application. The group works with Lawyers Council of Thailand, MAP Foundation, and other Thai NGOs to help laborers in matters related to legal issues (Chawalit, Interviewed on 9 March 2012).

Presently, YCOWA has about 10 staff members who provide information and assistance for transnational laborers as well as maintaining a safe house for Burmese transnational laborers who face problems. YCOWA also has about 700 members scattered in factories, business places and farms who report when there are cases about labor injustice (Oo, Interviewed on 12 March 2012). The establishment and activities of the "Flowers of the Dawn" described above corresponds with a study by Boissevain (1974) as the group began from Moe Sway, the leader of the organization and his Burmese friends. The scope of work gradually expanded as Moe Sway learned more about working in the area and used social networks, MAP, LLC, and government agencies in the area to coordinate activities which is in agreement with studies by Tsing (1960) and Lavie \& Swedenburg (1996). These studies gave importance to analyzing different power groups in the border area. However, they still see that the borderland is a political issue where people with more power drive the national economy which is different from Moe Sway's view which perceives that the life of transnational workers is more important than driving the economy forward even though it involves the economy. 


\subsection{Flowers of the Dawn's Operations as Mediators and Facilitators of Social Justice}

\subsubsection{Many Lives that have to Face Hardships}

There are 172 factories in the Mae Sot area with Thai and Burmese workers that are all registered, and the number of these workers accounts for 68.65 percent of all the workers in Tak Province. The number of transnational workers who entered Thailand illegally from Myanmar accounts for 84.49 percent of all the workers. Most workers work in textile factories. These figures reflect that Mae Sot is the largest industrial town in Tak Province. Furthermore, it is found that there are many transnational workers who work in the service sector such as working in homes as house cleaners, in restaurants as waiters, washing dishes, working in markets and shops, in small service stations, and in plantations. This is because Mae Sot has geographical characteristics suitable for production in the industry sector as well as the agriculture sector (Tak Industrial Council, 2002).

Since Mae Sot is an area suitable to be a production base for both the industrial sector and the agricultural sectors, increasingly more people flow from Myanmar to Mae Sot to live and to work in the area. As a result of interviewing key informants, it was found that transnational workers had to face their future alone without help from any organization. The problems found included low wages, overwork for extended hours (from 7.00 a.m. to 9.00 p.m.) without overtime pay, work permit being withheld by employers to prevent workers from changing to a new workplace, and to make it easy for employers to suppress wages. Moreover, these transnational workers are often treated unfairly by employers. For example, when they have an accident at work, the employer takes no responsibility; when female workers are sexually abused, they are not taken care of (Zaw, interviewed on January 11, 2012). Additionally, there were other problems that were told by Tawan (interviewed on January 13, 2012) and Moo Di (interviewed on January 12, 2012) who said “... if the worker stays in one place for too long, the employer doesn't want to hire this worker ... and sometimes he or she is laid off ...because he or she knows about human rights. It's a problem for the employer and so he or she does not continue the employment ... Some workers become assistants to employers ... become brokers ... to go back to Myanmar to find new workers. Sometimes workers have to find a new job in another factory, even though the wage at a new place is not better ... because if they do not do it, they will have nothing to eat ... going back to Myanmar, they may face persecution. If they have to be in prison, they would rather be in a Thai prison than a Burmese prison because in Myanmar they may be simply left in jail forgotten...

In addition, it was found that although the Thai state had policy of registering transnational workers but there were limitations in the registration process. In the first year of the process, there were many workers wanting to be registered because they thought that they would be protected. After that, fewer workers were registered because they were required to pay a registration fee but protection provided was not any different from when they were not registered (Jack, interviewed on January 12, 2012; Wanchai, interviewed on May 11, 2012).

The above phenomena reflect that many inividuals have to face hardships and they have to be patient and tolerate the problems that arise in order that they can remain a little longer, and this extends to those family members whom they have left behind.

5.2.2 Providing Help for Transnational Laborers as the Flowers of the Dawn, "Mediators and Facilitators of Social Justice"

The Flowers of the Dawn as mediators and facilitators of social justice have provided help by acting as mediators and coordinating negotiations with different groups as follows:

\section{1) Providing a sanctuary for homeless workers}

One important function is listening to transnational laborers talk about troubles they face and then trying to help them. If the problem is not serious, such as having no place to stay in or no job to do, then YCOWA can help them immediately. In 2002, some people managed find refuge in third countries, many of those went to Norway, earned some money and bought 10 sewing machines to donate to YCOWA. Five of the sewing machines are still in good condition and in use today. A Burmese named Ma Ei has been assigned to teach transnational laborers how to use the machines when they come to Mae Sot for the first time so that they have enough sewing skills to go out to work. They stay in the safe house for about one week to learn the sewing skills from Ma Ei who then takes them to factories that need workers with sewing skills. Ma Ei does this about 10 times a year and trains about 8-10 workers each time. Moreover, YCOWA helps workers who are unemployed, sick, and pregnant or sexual assault victims by giving them a place to stay in the safe house. YCOWA staff members hold a meeting agreeing to help workers and providing them with shelter and food (Oo, Interviewed on $12 \mathrm{March}, 2012$ ).

2) Negotiation with business owners and government officials about labor rights

The Flowers of the Dawn's work is to help workers who are exploited by groups and individuals. The group uses 
the social networks consisting of many groups such as MAP-Foundation, Labor Law Clinic for legal consultation, for finding lawyers and interpreters when talking with government official during legal proceedings.

During the interviews of a government official (Thinnakorn, interviewed on December 22, 2011) and an LLC staff member (Ann, interviewed on December 20, 2011), they said that one weak point of the policy on making Mae Sot a special economic zone and the economic promotion policy is that it allows international investors to invest in Mae Sot by coming in with just one suitcase and renting factories. They can invest without having to make any security deposits so that they can pay when they violate labor rights. As a result, workers have to wait for a long time to get compensation because of a long legal process which involves the checking, seizure, and auctioning of assets. However, the process can be considered a success and a positive experience for transnational workers to achieve a positive outcome after going through the legal process. Winning a case is not only an individual success but also promotes gaining confidence in the legal protection afforded to transnational workers.

The coordination of help for workers, whose rights were violated, was difficult at the beginning for the Flowers of the Dawn because workers did not have confidence that the group could achieve what they said and the workers did not want to face deportation. Workers do not have the right to stay in the country if the factory is closed resulting in their being unemployed. Without an employer, workers cannot live in Mae Sot. This agrees with what Praphat (interviewed on May 12, 2012) said, “... Even though workers have been registered with certain employers, ... when injustice is done to us ... in the past we just kept silent and no one helped us, and when stood for our rights, the employers laid us off..." When a case is brought to court, the employer hires a tricycle driver to act as our employer. So he has no assets for the government to confiscate. Workers have no documents to present when going to court because all documents necessary for employment that they signed before began to work were all in Thai. They have no salary slips. They get pay after expenses for rent and food are deducted even though they were told that the accommodation was free and rice was cooked for them for free three meals a day but they had to by other food (Oo, interviewed on March 11, 2012).

A case can be brought to court only for registered workers. The Flowers of the Dawn and other social networks can help them depending on facts only. Therefore, before going to court, workers have to go through negotiation with their employers first. If after the negotiation, both parties can reach an agreement, then the case is terminated. However, if they cannot reach an agreement, the case is taken to the labor court, for which coordination with the government organization, i.e. the Mae Sot branch office of Labor Protection and Welfare, Tak Province, is required. The Flowers of the Dawn has fought and won important cases for workers, especially since, forms used in employment department have been translated into the Burmese language, and Office of Labor Protection and Welfare that was previously only in Tak City, now has a branch office in Mae Sot, too (Kan, interviewed on December 20, 2012).

Nowadays, staff members of the Flowers of the Dawn and volunteers that infiltrate workplaces and industrial facilities have been sent to the MAP-Foundation in Chiang Mai every year to be trained and to gain knowledge about labor laws. After such training, they work as legal consultants for transnational laborers at the office of the Flowers of the Dawn or do proactive activities such as talking with transnational workers at their factories to pass on knowledge to them during their lunch hour or in the evenings after work (Tuinai, interviewed on April 11, 2012; Kosat, interviewed on April 12, 2012).

The above phenomena reflect that before the transnational workers met the Flowers of the Dawn, they never thought that they would receive justice and they dared not demand anything from their employers because they were afraid of losing their job, and the potential consequences of doing so. As can be seen, working to provide help for transnational laborers is time-consuming for the group, the Flowers of the Dawn. According to Hibrue (interviewed on May 10, 2012), “... it takes so long for a case to finish. The money I had left was not enough for food and for fighting the case. Some friends just said goodbye leaving me to wait and fight the case. But now we don't have to wait there; we can go back to work. When they want us, they just telephone us. Otherwise, we won't survive..." In order for workers to be able to negotiate with employers, government officials and some employers agree that we should work to help transnational laborers because the government sector alone cannot take care of them completely. In addition, business people who work with transnational workers will be talked about negatively. It is believed that organizations that provide help for transnational workers in this area, especially those who are Burmese can understand problems better than the government sector. It is agreed that there should be interpreters in government offices and places of employment where transnational workers have to interact (Leng \& Somchai, interviewed on July 25, 2012). The Flowers of the Dawn was awarded the 8th Tji Hak-soon Justice \& Peace Award in 2004 from the Republic of Korea for its work in protecting workers from 
injustice and violation of their human rights.

From 2005, the Flowers of the Dawn have changed its modus operandi in perceiving problems and fighting cases. The group used to bring workers to take shelter at the safe house while the case was in process which usually took a long time. However, now the group encourages workers to go to work and when they need to be present in the court, the group telephones the workers. The help provided by the group is considered according to the merits of each case and the group acts as a mediator in negotiation between the transnational workers and the employers. If the negotiation is not successful, the case is sent to court and the group find a lawyer to represent the worker. After the case has been processed but still unsatisfactorily for the worker, the group gather other workers to peacefully protest at the court. Through these methods, many problems resulting from negligence on the part of the government sector have been solved or mitigated even though not every one of them could be solved completely. The Flowers of the Dawn has been able to make businessmen and government officials see the importance of human rights for transnational workers and not just ignore them (Suthisak, interviewed on January 14, 2012).

During 2008-2011, the Flowers of the Dawn in conjunction with lawyers from MAP-Foundation and the Lawyers Council of Thailand fought cases for transnational workers who were not paid their wages or compensations and could help 1,835 workers who received compensations form owners of 132 factories totaling $10,737,428$ Baht. The group won the cases through Thai legal processes, the Flowers of the Dawn, is thus considered to have potential in successfully provides help for transnational workers in addition to knowledge of labor rights and human rights through radio FM102.5 MHz broadcasting in the Burmese language and Keren language. It also provides knowledge through printed materials in the form of a monthly magazine distributed to transnational workers so that they receive news about movements and other activities.

\section{3) Providing healthcare knowledge and lunches for schoolchildren}

To assist with human rights issues, knowledge on healthcare, advice on how to obtain services in hospitals and providing lunches for children, the organization established a self-supporting clinic called Clinic Mobile in Mae Sot District to provide door-to-door health services for Burmese laborers and provides lunch for school children everyday in order to help parents who cannot take their children with them to work (Tuinai, Interviewed on 11 April, 2012).

4) Jointly organizing activities on important days

The organization jointly organizes activities with government and private organizations on important days such as International Women's Day and National Labor Day by sending staff to participate in organizing activities to highlight the scope of the organization's work and to provide knowledge of human rights, laws, women's rights and healthcare rights (Kiki, Interviewed on 12 April, 2012).

5) Coordinating issues on human rights and women's rights

Presently, YCOWA has expanded the scope of its work to cover issues such as human rights and women's rights by helping women who are victims of sexual assault, organizing funerals for people who were unlawfully killed, collect evidence for legal actions, helping laborers who are forced to do certain types of work and/or are victims of human trafficking. YCOWA helps laborers to be free, helps negotiate laborers' wages and facilitates their return to Myanmar. Ma-Ii, a staff member who takes care of rape victims said:

“....in 2011, two women were raped by a 40 -year old man ... one woman was injured and her intestine came out ... Yaung Chi Oo has taken care of over 30 rape victims since I have been here. Some told me that when they reported their cases to the police, they needed to have their body examined and had to explain how it happened ... Some women dared not report their cases to the police. Some came to tell Yaung Chi Oo and disappeared ... Most women who reported their cases to the police were widows or married ... If it happens to women who are not yet married, they are too embarrassed to report it to the police ..." (Ei, Interviewed on March 11, 2012).

“... The problem now is that ... why so many women do not want to report it to the police or enter the process of justice ... because when the court procedure ends ... they will be sent back home right away ... Well, they don't have a status to be here ..." (U-sob, Interviewed on 14 January, 2012).

The above data reflect that the help provided by the Flowers of the Dawn has been expanded more extensively. Help that used to be provided for only laborers have been expanded to cover children and women who have been abused and sexually assaulted. Ma Ei is the one taking care of issues concerning women's rights.

The work process of the Flowers of the Dawn as mediators and facilitators of social justice is in agreement with 
a study by de Certeau (1984) that claims that in activities of daily living, there are "tactics" hidden in the work process. In the practice of the Flowers of the Dawn in negotiating with entrepreneurs, government agencies, and transnational workers, various tactics are used such as providing knowledge, providing help directly in matters related to law, providing shelter, participating in activities of the government sector on important days, etc. Tactics are used in order to compete, negotiate, and manage authoritative relationship. The work of tactics refers to insinuation into an authoritative area. Therefore, the Flowers of the Dawn uses social networks in the Mae Sot borderlands such as its own members, NGOs, CBOs, and INGOs to coordinate its work for achievement.

\section{Conclusion}

Providing assistance for transnational laborers as "mediators and facilitators of social justice" by the Flowers of the Dawn began when the some people saw hardships faced by their fellow Burmese transnational laborers, especially in terms of labor injustice, and then got together to form a group to provide help and to act as a middleman to arbitrate between employers and transnational laborers. The group joins hands with other organizations such as MAP-Foundation and the Lawyers Council of Thailand to provide help for transnational laborers in giving shelter, organizing sewing skills training, finding jobs, providing knowledge of labor laws and labor rights through radio, printed media, talks at business places and residences, assisting in fighting cases, giving help in healthcare, sickness, providing childcare for children of transnational laborers, and giving help to victims of human trafficking and women who are victims of sexual assault.

\section{Acknowledgements}

We are grateful to the Thailand Research Fund (TRF) for support for this project.

\section{References}

Appadurai, A. (2002). The Anthropology of Globalization: A Reader. Blackwell Publishing.

Benedict, A. (1991). Imagined Communities: Reflections on the Origin and Spread of Nationalism. London and New York: Verso.

Billington, R. (1967). The America Frontier. In P. Bohannan, \& F. Plog (Eds.), Beyond the Frontier: Social Process and Cultural Change (pp. 23-25). New York: American Museum Sourcebook in Anthropology.

Boissevain, J. (1974). Friends of Friends: Network, Manipulators and Coalitions. Oxford: Basil Blackwell.

Boonprakarn, K. (2008, Oct 2007-March 2008). The Construct of Social Identities of Cross-border Clothes Consumers at the Padang Besar, Thai-Malay Borderlands. Journal of Thai Studies, 5(1), 69-102.

Boonprakarn, K. (2010, Jan-June). Muslim Traders Across-border: Their Everyday Lives Practice in Padang Besar, Thaiand-Malaysia Borderlands. Journal of Liberal Arts, 2(1), 1-25.

Burmese Firms Set Up Shop in Thailand (King-Oua Laohong). (2009, May 18). Bangkok Post, 2.

Burmese Politics. (2003, April 25). Retrieved from http://www.irrawaddy.org

Chantarawongkitti, K., \& Boonprakarn, K. (2013, April 27). Meanings and Social Network Creation of the Animal Lottery in an Industrial Factory. 5th International Conference on Humanities and Social, April 27th, 2013 at BP. Grand Tower Hotel, Hat Yai. Songkhla: Faculty of Liberal Arts, Prince of Songkla University.

de Certeau, M. (1984). The Practice of Everyday Life. Berkeley: University of California Press.

Doorairajo, S. D. (2002). No Fish in the Sea: Thai Malay Tactics of Negotiation in a Time of Scarcity. Doctor's Thesis. Harvard: Harvard University.

Gupta, A., \& Ferguson, J. (2001). Beyond 'Culture' Space, Identity and the Politics of Difference. In A. Gupta, \& J. Ferguson (Eds.), Culture Power Place Explorations in Critical Anthropology (pp. 33-51). London: Duke University Press.

Highmore, B. (2002). Everyday Life and Culture Theory: An Introduction. London \& New York: Routledge.

Horstmann, A. (2002). Incorporation and Resistance: Border Transnational Communities and Social Change in Southeast Asia. Tokyo: University of Foreign Studies.

Jirattikorn, A. (2007). Living on Both Sides of the Border: Transnational Migrants, Pop Music and Nation of the Shan in Thailand. Chiang Mai: Faculty of Social Sciences, Chiang Mai University.

Kasetsiri, C. (2011). Burma: History and Politics (4th ed.). Bangkok: Thammasat University Press.

Khunphon, S. (2007, May-August). The Everyday Life Practice. Journal of Political Science, 28(2), 113-146.

Kosaiyakanon, P. (2004). Migrant Industrial Workers in the Thailand-Burma Borderland: A Case Study of 
Burmese Nationality Workers in Mae Sot District, Tak Province. Thesis for Master of Science in Geography, Graduate School, Chiang Mai University.

Lavie, S., \& Swedenburg, T. (1996). Displacement, Diaspora, and Geographies of Identities. Durham: Duke University Press.

Leach, E. R. (1954). Political Systems of Highland Burma. London: Athlone.

Samosorn, A., \& Boonprakarn, K. (2011, April 2). The Definition and Social Networking of Underground Lottery. The 3rd International Conference on Humanities and Social Sciences April 2, 2011at Faculty of Liberal Arts, Prince of Songkla University (pp. 1-16). Songkhla: Faculty of Liberal Arts, Prince of Songkla University.

Solomon, R. (1970, September). Boundary Concepts and Practices in Southeast Asia. World Politics, 23(9), 1-23. http://dx.doi.org/10.2307/2009628

Sorat, T. (2012, June 25). Opportunities and Feasibility in Establishing a Special Economic Zone (Border) at Mae Sot District, Tak Province. Retrieved June 25, 2012, from http://www.tanitsorat.com/view.php?id=85

Sretthachua, C. (2009). Tactics of Everyday Life Practice of Cambodian-Lao Migrant Workers in Thailand in the Context of Mekong Regionalization. Journal of Mekong Societies, 5(2), 26.

Suwanatchariya, C. (2006). Social Network. Mahasarakham: Mahasarakham University.

Tangseefa, D. (2004). Looking Through “the other” Karen's Eyes at the Methodology for the Forced Displaced Persons in the Area between Thailand and Burma. Journal of Thai Studies, 1(1), 154-196.

The 8888 Uprising in Burma. (2012, March 25). Retrieved from http://www.guru.sanook.com/history/topic/2160

Thongsakul, H., \& Boonprakarn, K. (2012, Jan-June). The Meaning Given to an Area for Having Tea in Khu Tao Community. Journal of Liberal Arts, 4(1), 78-91.

Tsing, A. (1960, March). The Frontier of Burma, in the Comparative. Studies in Society and History, 3(1), 49-68.

Walker, A. (1997). The Legend of the Golden Boat: Regulation, Transport and Trade in North-Western Laos. Doctor's Thesis. Australia: The Australian National University.

Wangpherm, C. (2012, April 22). Following "Foreign Workers" to the Edge of Mae Sot. Matichon Daily.

Wilson, M. T., \& Donnan, H. (1998). Border Identities: Nation and State at International Frontiers. Cambridge: Cambridge University Press. http://dx.doi.org/10.1017/CBO9780511607813

Winichakul, T. (1994). Siam Mapped: A History of the Geo-Body of a Nation. Chiang Mai: Silkworm Books.

\section{Interviewees}

Ann. (2554, Dec 20). Staff of LLC, interviewed at Labor Law Clinic, Mae Sot District, Tak Province.

Chawalit. (2012, March 9). Official interviewed in front of Office of Mae Sot District, Tak Province.

E Mun Oo. (2555, March 11). Transnational worker, interviewed at a factory in Tambon Mae Ku Nuea, Mae Sot District, Tak Province.

Hybru. (2555, May 10). Staff of MTC, interviewed at Mae Tao Clinic, Mae Sot District, Tak Province.

Jack. (2555, Jan 12). Staff of LLC, interviewed at Labor Law Clinic, Mae Sot District, Tak Province.

Kant. (2554, Dec 20). Staff of HRDF, interviewed at Human Rights and Development Foundation, Mae Sot District, Tak Province.

Kiki. (2012, April 12). Staff of YCOWA, interviewed at Yaung Chi Oo Office, Mae Sot District, Tak Province. Ko Sat. (2012, April 12). Staff of YCOWA, interviewed at Yaung Chi Oo Office, Mae Sot District, Tak Province. Leng. (2555, July 25). Factory owner, interviewed at factory of Mae Pa, Mae Sot District, Tak Province.

Ma Ei. (2012, March 11). Staff of YCOWA, Interviewed at Yaung Chi Oo Office, Mae Sot District, Tak Province.

Ma Naw. (2012, January 11). Transnational worker, interviewed at Si Hong Factory, Ban Mae Pa, Mae Sot District, Tak Province.

Ma Oo. (2012, March 12). Transnational worker, interviewed at Yaung Chi Oo Office, Mae Sot District, Tak Province. 
Moe Sway. (2012, January 11). Staff of YCOWA, interviewed at Yaung Chi Oo Office, Mae Sot District, Tak Province.

Moo Di. (2012, January 12). Transnational worker, interviewed at Yaung Chi Oo Office, Mae Sot District, Tak Province.

Myo Zaw. (2012, January 11). Staff of YCOWA, interviewed at Yaung Chi Oo Office, Mae Sot District, Tak Province.

Prapat. (2012, May 12). Transnational worker, interviewed at Yaung Chi Oo Office, Mae Sot District, Tak Province.

Somchai. (2555, July 25). Factory owner, interviewed at a factory in Tambon Mae Ku Nuea, Mae Sot District, Tak Province.

Suthisak. (2012, January 14). Staff of MAP, interviewed at MAP Foundation Office, Mae Sot District, Tak Province.

Tawan. (2555, Jan 13). Transnational worker, interviewed at Yaung Chi Oo Office , Mae Sot District, Tak Province.

Taye. (2012, January 13). Transnational worker, interviewed at Si Hong Factory, Ban Mae Pa, Mae Sot District, Tak Province.

Thinnakorn. (2554, Dec 22). Official at Labor Protection and Welfare Unit, interviewed at Office of Labor Protection and Welfare, Mae Sot District, Tak Province.

Tuinai. (2012, April 11). Staff of YCOWA, interviewed at Yaung Chi Oo Office, Mae Sot District, Tak Province.

U-sob. (2012, January 14). Staff of MAP, interviewed at MAP Foundation Office, Mae Sot District, Tak Province.

\section{Copyrights}

Copyright for this article is retained by the author(s), with first publication rights granted to the journal.

This is an open-access article distributed under the terms and conditions of the Creative Commons Attribution license (http://creativecommons.org/licenses/by/3.0/). 